\title{
Analysis of The Leading Role of Ideological Education on The Undergraduate Career Development Plan
}

\author{
Xiaoyun $\mathrm{Li}^{1}$ \\ ${ }^{1}$ Jilin Institute of Chemical Technology, Jilin City, Jilin, China
}

\begin{abstract}
It is very important to develop the leading role of the ideological education from university to the undergraduates as the employment situation is severe for them. This article analyse how to realize the leading role of ideological education on the future career plan for the undergraduates on the basis of its urgency and necessity.
\end{abstract}

Key words: undergraduate, ideological education, career development plan

\section{Introduction}

With the changes of college students' employment situation, how does the core effectiveness play an important role in college students' career planning has become an important part of ideological education. Ideological education helps college students to establish a correct outlook on world, outlook on life and sense of worth [1], promoting social theme and positive energy, paying attention to moral education, and constantly improving the humanities of college students, in order to make $\mathrm{s}$ tudents achieve their own value and social value whether work or life in the future career.

\section{The necessity of strengthening ideological education in college students' career planning}

Playing an effective role in the career planning of college students, the ideological and moral education mainly includes two aspects: One is the basic education of moral character; the other is socialistic professional quality education. The cultivation of good moral character can help college students grow up. Nowadays, wide ranges of material wealth were created, while our spirit and soul have begun to appear blank. In modern times, an era that related with faith, soul, and spirit of the Chinese start. When college students are about to go to the society and meet all kinds of opportunities and challenges, how can they grow up? In a certain sense, it is not only just relying on talent, but moral character, set what kind of life goal and pay how much effort. To make students learn to behave, learn to do things, and adapt to the development of society rapidly through ideological education, so that students can establish their own outlook on life and world on a new moral level. The cultivation of mature employment ideas can ease the pressure on the employment of college students. Professional ethics is one of the most important qualities, including honesty and faithfulness, dedication and workhard, serving the people, and contributing to society. With increasing pressure on the employment of college students in our country, according to the educational guide direction of colleges and universities, to help students establish correct outlooks and employment view consistent with the social development, to strengthen the college students' psychological ability when they face problems that may arise in the employment, to strengthen the cultivation of students' professional ethics and quality, will continually to improve the core competitiveness of college students, alleviate the employment pressure [2], they can get a job as soon as possible to adapt the society.

\section{The common problems of the ideological education in the college students' career planning}

Self-awareness is not clear, and the ideal deviates from reality. Self-cognition is a very important content in college students' career planning, which should have a clear judgment to themselves. Some students cannot understand themselves well, which affect the accuracy of career planning. At 
present, college students' selforientation is different because of the different background of family, the ability of learning and living, and the difference of knowledge. Some of the students are too idealistic and emotional of the cognitive and thinking; and their mind is not mature enough.

The value orientation is biased, and the utility tendency grows.Along with the rapid development of economy, some shortterm behavior, utilitarian ideas grow, influence the value orientation of college students and career choice, a majority of students pay more attention to immediate interests, the goal is too simple, tend to money and power,In the choice of specific occupation, some college students over the pursuit of economic efficiency, but not pay attention to the professional growth, less consideration in the work to feel the responsibility and play. If we ignore the ideal, faith and beauty, will weaken their own value and social value.

Professionalism is not enough, psychological quality is weak. Professional quality mainly includes ideological and political quality, professional ethics, professional psychological content. Current college students' psychological quality is poor, not very good adaptation the social needs for talents of. On the one hand, they accepted traditional education in thought actively to the party organization closer, the other aspects in the face of the rapid development of social economy, culture is relatively lagging behind some negative thoughts such as money worship, graft and corruption and the lack of a firm political belief. The social moral lose Fan behavior despite knowing that the contempt, but a but for short-term personal interests and to follow. It is a serious impediment to the correct orientation of the construction of professionalism of college students.

\section{The important factor of College Students' employment difficulty is that they are too idealistic and unitary, and the formation of correct ideas will become the core content of College Students' employment and entrepreneurship education.}

Clear ideologicaleducation in the professional career planning of moral training objectives.

First, guide students to make a rational person. Firstly, rational people should have ideals. One important factor to success is in the ideal, behavior goals, opportunities are always reserved for desire and unremitting efforts of the people. Secondly, a rational person should be objective and calm in the face of complex things. The major problem to be calm, realistic, do not swim in a rational manner, and overcome the social strength to face in filthy mire. Once again, the rational man will go beyond the utilitarian gains. Although we live in the physical world, but the mind must not be utilitarian purpose, the behavior must not be for money the domination, judgment is the standard should not be the money and power, but should be fair and justice and social conscience of humanity.

Second, guide college students to do a responsibility. Responsibility is to the society, the family always willing to pay, the courage to play. First of all, to the national and social responsibility have served as a service consciousness of others. The social anomie phenomenon, not only a critic, but can not become a drift of the follower, and should become a responsible play construction. Secondly, to do a family responsibility, respect, care, the parents return to repay them for their selfless dedication to raise graciousness; into the family life, to further training, maintenance, perfect marriage, a family is responsible for the people.

Third,guide student to do a man of virtue. Virtue should conduct is a virtue, spared. First of all, "A man with good quality can make a career". In the face of public entrepreneurship, trend of millions of reform and innovation, personal development space is more and more broad. Things in life to moral preoccupation, to the correct path to do poineering work, not for power around, so that the interests of submerged conscience. Secondly, in a complex environment to be spared. "Not to be a small evil to, do not in the good small'Be a sober and cautious person.

Teach college students ideological education by stages and by the numbers. For the reasons that college students have no common ideas in cognitive ability, specific character and hobbies, we should share our courses, ideological education, in numbers at each stage including the stage about entrolling, learning major subject and graduating fromschool.We should take steps to teach 
ideological education, under the basement that keep their sound in body and mind healthy,also develop and expand positive energy in society.

At the entrolling stage, the freach students have no awareness about most things, which means they maybe have no clear life goal and ideal,such as the courses to choose, the direction to follow. Thus, when giving the choice about ideological education, we teacher must make students set up correct three reflections; know themselves in the round, raise the comprehend in the thought.Introducing the typical examples with their life idea or trajectory to raise the awareness of thought, awareness to politics and the norm for morality step by step,untill it integrates into everyday's behaviour.

At the stage taking their major subject, which is the prepare stage for college students before they get into work, when they spend the middle two years in school.through which they wii obtain capitity to know how to choose job.It is the erudite knowledge that help build up the basement and condition for their way to success.Above all,it is important and necessary to set up completedknowledge theory.Profession accomplishment accountant for amost in the feed back system. Of course it also decides whether they would be accepted by workmates, identified with leaders and society.profession accompletement play a role as leader in college students' job development in the futhure.if we were researching ideological education in an ensemble, we must put patriotism, collectivism and profession accompletement education among students together.

At graduation education stage,stress the choice leading to job in ideological and political eaucation .help them set up correct awareness of job choice and positive awareness of obtaining occupation.strengthen the endurance capacity in mind and the capacity to resist beat and so on.Guidance them get all ready before taking a job,espeacilly, the correct awareness of selfemployed.Nowadays, our country spread most preferential policy to self-employed when college students need,part of them may try it on basing his interester.At graduating stage in ideological education, osmosis self-employed thought in all aspect,making students in need get the fit objects,then,reliefing the pressureof employment.

Brackets three, System synthesis, mobilize all the staff to participate in the ideological education.

Have to educational work in college and university mainly includes and system of education management system and service system in three big system. In the ideological education should be closed be closed linked, so that the students onto the road of adult success.

Firstly,gradually enriching the connotation of the ideological and political theory course education. The content of career planning and ideological and political theory course teaching.For example, in the freshman year of "thought morals tutelage and legal foundation" course, emphatically carries on the patriotic education, collective education and career ideal ,etc.In the course of "Marx" basic principle", it strengthen the thought of right outlook on life,values education and the realization of comprehensive development during my college second year.

In the course of "Mao zedong thought and theoretical system of socialism with Chinese characteristics" . It strengthens the education of the domestic and foreign situation, finance or politics. In the course "Chinese modern history outline" of junior, value orientations, and emphatically analyzed historical figures of career choice, deepen students' awareness on the depth of career choice too!

Secondly, all aspects of the whole ideological education of ideological education to the staff responsible for the leadership of ideological and political work should also include career guidance center departments have to secretary of the counselor and a teacher's teacher in charge and other party leaders to support teachers from macro policies in their respective jobs through ideological education work in the specific work everyday as a dominant force to counselors and teachers should also be understanding faculty and student dormitory students ideological trend to carry out day-today work of the school ideological and political work related departments have effectiveness can organize regular some successful people experts lecture effect the value orientation of the form noble. 


\section{Conclusion}

To sum up, in recent years, along with the social transformation and the era of mass higher education get to college graduates employment problem has become a focus in the area has been increasingly concerned all the way to the national strategy and promote public entrepreneurship has innovation in the process of great science to their own career planning is a very real problem. The ideological education for college students' ideal faith on the value orientation of moral quality to shape and cultivate college students' moral cultivation relieve the strain on the current employment situation when students leave school take away not only knowledge is more important is to have noble quality and how to career planning and ideological education effective combine is an important job.

\section{References}

1. Chen,Shuyuan.Analysis The Graduates' Career Development Courses Ideals And Convictions[J].Journal of Taiyuan Urban Vocational College,2015(3):129

2. Gao,Jian. Survey of Ideological education on College Students' Career Development[J].Education and Vocation,2015 (2):83

3. He Lingling.Education Of College Students' Career Development about Ideological and Political[J].The Science Education Article Collects,2015 (2): :18

4. Xu,Hui.Survey Of Ideological education on College Students' Career Development[J].Journal of Hubei Correspondence University,2015 (28):49

5. Chen, Shuqin.The Effective Realization and Combination of College Ideological education and Career Planning[J]. Journal of Taiyuan Urban Vocational College,2015 (6):52

6. Gao,Yanzheng.Survey of Ideological education on College Students' Career Development[J].Education Forum,2015（3）:24

7. Meng,XiaoYuan.Survey of Career Education as a Starting Point for Effective Innovation and Improvement Ideological education[J].Science and Technology Innovation Herald,2015(6):124 